\title{
Removal of Boron from Silicon by Moist Hydrogen Gas
}

\author{
ERLEND F. NORDSTRAND and MERETE TANGSTAD
}

\begin{abstract}
New and cheaper refining methods for production of metallurgical silicon are needed to meet the increasing demands for low-cost, high-quality silicon for the solar cell industry. One promising refining method for boron is moist hydrogen treatment. In this work, an evaporation unit has been used to produce wet hydrogen gas, which subsequently has been sparged on top of silicon melts. The effect of temperature and gas composition on boron removal has been studied. The main results show that boron is removed from liquid silicon and the removal rate is controlled by chemical reaction depending on $p_{\mathrm{H}_{2} \mathrm{O}}$ and $p_{\mathrm{H}_{2}}$. Water vapor treatment of molten silicon can alone remove boron. However, in combination with hydrogen gas, the removal rate is significantly increased. In addition, the rate of boron removal in silicon has been found to decease with increasing temperature.
\end{abstract}

DOI: $10.1007 / \mathrm{s} 11663-012-9671-1$

(C) The Author(s) 2012. This article is published with open access at Springerlink.com

\section{INTRODUCTION}

TRADITIONALLY, off-spec polycrystalline silicon from the semiconductor industry, produced through the Siemens process, has been supplying the solar industry. ${ }^{[1]}$ This silicon is both costly $(<\$ 35$ per $\mathrm{kg}, 2009)$ and far purer ( 9 nines) than that what is needed for PV applications (6 nines). ${ }^{[2]}$ To make solar cells less expensive, it has been necessary to develop production methods for solar silicon that improve cost and efficiency. ${ }^{[3]}$ Many methods have been patented the last decades by companies like Elkem, Fesil/SINTEF, and Kawasaki/NEDO, ${ }^{[4-6]}$ where the target has been to produce 6-nines pure solar grade silicon (SoG-Si) at approximately $\$ 15$ per $\mathrm{kg}$. These methods have often been referred to as the metallurgical route compared with chemical route by the Siemens process.

In the metallurgical route, boron is particularly difficult to remove because of its high segregation coefficient and low vapor pressure. ${ }^{[7]}$ From the metallurgical production of silicon (MG-Si), approximately 95 pct of the boron put into the process remains in the product, and boron is for the most part linked to the impurity levels in coke (61 pct) and quarts (37 pct). Carefully choosing the charge materials is, therefore, the first step in lowering the boron content. ${ }^{[8]}$

To meet the limit of the accepted boron content in SoG-Si $(<0.5$ ppmw B), a purification step is needed. A practical way to do this is through plasma refining. ${ }^{[9-11]}$ In plasma refining, the heat of the plasma torch activates gases such as oxygen and hydrogen on the silicon surface to produce volatile $\mathrm{H}-\mathrm{B}-\mathrm{O}$ species. ${ }^{[12]}$ This method requires less handling of materials compared with slag refining. ${ }^{[13,14]}$ Still, the process is relatively expensive

ERLEND F. NORDSTRAND, Scientist, and MERETE TANGSTAD, Professor and Scientist, are with the Norwegian University of Science and Technology, 7491 Trondheim, Norway. Contact e-mail: erlendfj@nt.ntnu.no

Manuscript submitted November 9, 2011.

Article published online May 1, 2012. because of the high energy consumption of the plasma torch. It has, therefore, been desirable to develop new and cheaper ways for boron removal using reactive gasses.

In this work, an evaporation unit will be used to add water vapor to $\mathrm{H}_{2}$ gas, which subsequently will be sparged on top of silicon melts. From these results, the effect of temperature and gas composition during gaseous boron removal will be studied.

\section{THEORETICAL BACKGROUND}

It was already demonstrated in 1956 by Theuerer ${ }^{[15]}$ in a zone refining reactor that boron could be removed by treating the surface with moist hydrogen. However, it was not until the late 1980s and the entry of metallurgical production of SoG-Si that reactive gas blowing was shown considerable interest. Suzuki et al. ${ }^{[16]}$ used plasma to purify $5 \mathrm{~g}$ MG-Si on a water-cooled block and achieved 99 pet removal of boron using an $\mathrm{Ar}-\mathrm{H}_{2} \mathrm{O}$ mixture. The removal rate was relatively slow because of the small reaction area. Later, Ikeda et al. ${ }^{[17]}$ demonstrated, using a rotational torch that enlarged the contact area, that the treatment time could be significantly reduced. Subsequent development in the last decade has led to large industrial-scale plasma experiments carried out within the NEDO project. $^{[18]}$

\section{A. Effect of Gas Composition During Gaseous Boron Removal}

The most documented treatment gas for gaseous boron removal in silicon is water in combination with an inert gas or hydrogen. Separate treatment with hydrogen or oxygen has proven to have little or no effect. ${ }^{[1,16,17,19]}$ It has therefore been generally accepted that boron is volatilized as an oxyhydride. Nakamura et al. ${ }^{[18]}$ showed that the rate of boron removal is proportional to the water content in the gas during plasma refining. But this is true only up to a $p_{\mathrm{O}_{2}}$ where 
silica starts to form excessively on the surface. Alemany et $a l .{ }^{[19]}$ continuously analyzed the flue gases by inductively coupled plasma (ICP)-optical emission spectrometry while increasing $p_{\mathrm{O}_{2}}$ in the treatment gas, and a steep drop in deboronization rate was observed visually as a silica "skin" formed on the surface.

$\mathrm{H}_{2}$ gas increases the boron removal rate significantly when added to the plasma gas. ${ }^{[18]}$ One suggested mechanism for this is that $\mathrm{H}_{2}$ prohibits $\mathrm{SiO}_{2}$ formation, which increases the real reaction area because of less surface silica. This can, to some extent, be explained by the $\mathrm{Si}-\mathrm{H}-\mathrm{O}$ phase diagram in Figure 1, which shows decreasing stability of $\mathrm{SiO}_{2}$ with increasing $p_{\mathrm{H}_{2}}$.

It is, however, questionable whether this alone can clarify the considerable effect $\mathrm{H}_{2}$ gas has on the boron evaporation.

Other treatment gases have also been attempted for deboronization of silicon, such as $\mathrm{HCl}$ and $\mathrm{NH}_{4}$, but they have proven ineffective. ${ }^{[20,21]}$

\section{B. Kinetics of Gaseous Boron Removal}

It was shown in the previous section that the removal rate of boron in liquid silicon is strongly dependent of the chemical reaction between boron, water, and hydrogen up to a point where silica formation becomes the rate-limiting step. The rate $(r)$ of the reaction at moderate values of $p_{\mathrm{H}_{2} \mathrm{O}}$ can be written as

$$
r=k^{\prime \prime} \cdot[\mathrm{B}]^{l} \cdot\left[\mathrm{H}_{2} \mathrm{O}\right]^{m} \cdot\left[\mathrm{H}_{2}\right]^{n}
$$

where $k^{\prime \prime}$ is the rate constant $\left(\mathrm{s}^{-1}\right),[\mathrm{B}]$ is the concentration (ppmw), and $l, m$, and $n$ are the order of the reaction with respect to the concentration term.

However, when the concentration of water and hydrogen is kept constant, the rate of boron removal becomes pseudo-first order (where $l=1$ )

$$
r=-d[\mathrm{~B}] / d t=k \cdot[\mathrm{B}]
$$

where

$$
k=k^{\prime \prime} \cdot\left[\mathrm{H}_{2} \mathrm{O}\right]^{m} \cdot\left[\mathrm{H}_{2}\right]^{n}
$$

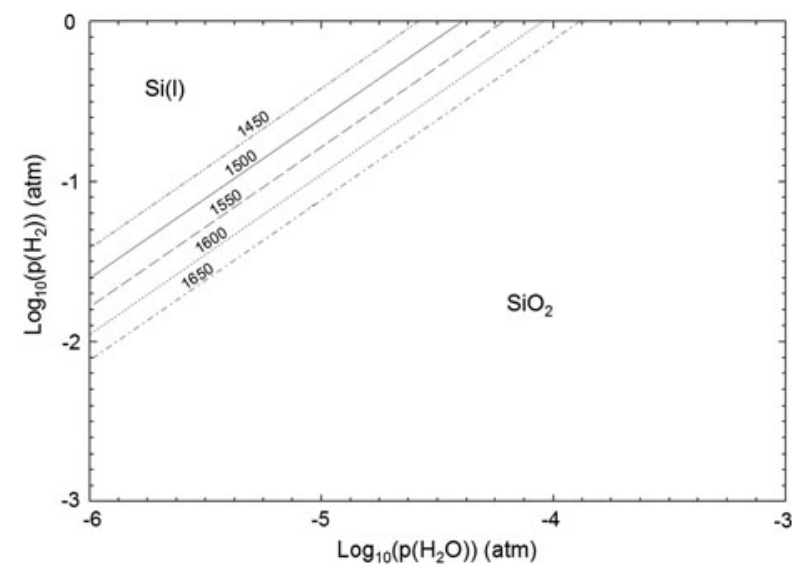

Fig. 1-Si-H-O phase diagram showing the equilibrium between $\mathrm{Si}(\mathrm{l})$ and $\mathrm{SiO}_{2}$ at different partial pressures of $\mathrm{H}_{2} \mathrm{O}$ and $\mathrm{H}_{2}$ between $1723 \mathrm{~K}$ and $1923 \mathrm{~K}\left(1450{ }^{\circ} \mathrm{C}\right.$ and $\left.1650{ }^{\circ} \mathrm{C}\right)$.
By integration the rate equation turns into

$$
\ln \left([\mathrm{B}] /[\mathrm{B}]_{\mathrm{o}}\right)=-k \cdot t
$$

where $t$ is time (s) and $[\mathrm{B}]_{\mathrm{o}}$ is the initial concentration (ppmw).

Available data in the literature for gaseous boron removal are reproduced in Figure 2 and show good correlation with the first-order rate constant. ${ }^{[16-18]^{6}}$

If the reaction area $\left(A, \mathrm{~m}^{2}\right)$ and the volume $\left(V, \mathrm{~m}^{3}\right)$ of the melt are known, the mass transfer $\left(k^{\prime}, \mathrm{m} / \mathrm{s}\right)$ in the reaction can be calculated by

$$
k^{\prime}=k \cdot(V / A)
$$

For the three data set in Figure $2(1-3)$, the $k^{\prime}$ yields $1.3,7.7$, and $7.0\left(\mathrm{~m} \mathrm{~s}^{-1} \times 10^{-5}\right)$, respectively.

\section{The Thermodynamics of Volatile Boron Spices}

The commercial available software FactSage 5. $0^{[22]}$ has in Figure 3 been used to calculate the partial pressures of gaseous species in the $\mathrm{H}_{2}-3.2$ vol pct $\mathrm{H}_{2} \mathrm{O}$ $\mathrm{Si}-\mathrm{B}$ system with $\mathrm{B} / \mathrm{Si}$ ratio $10 \times 10^{-6}$ at different temperatures. Here, the silicon melt is regarded as a dilute solution with respect to boron and Henry's law is obeyed (coefficient of activity, $f([\mathrm{~B}])=1$ ).

$\mathrm{HBO}(\mathrm{g})$ has been considered the most volatile boron substance in the literature, ${ }^{[19,24,25]}$ and this is in agreement with current calculations, as shown in Figure 3. HBO is approximately two orders of magnitude more volatile than the most stable boron oxide and hydride. However, the partial pressures of the gaseous boron species in this system are in general so low that efficient boron removal in practice should be difficult, according to thermodynamics. As an example, a $200 \mathrm{~g}$ silicon melt with 10 ppmw B treated with $810-\mathrm{L}$ $\mathrm{H}_{2}-3.2$ vol pet $\mathrm{H}_{2} \mathrm{O}$ (the amount used in this work) should at equilibrium evaporate 14 pct silicon and 18 pet boron according to the partial pressures of $\mathrm{SiO}$ and $\mathrm{HBO}$ in Figure 3.

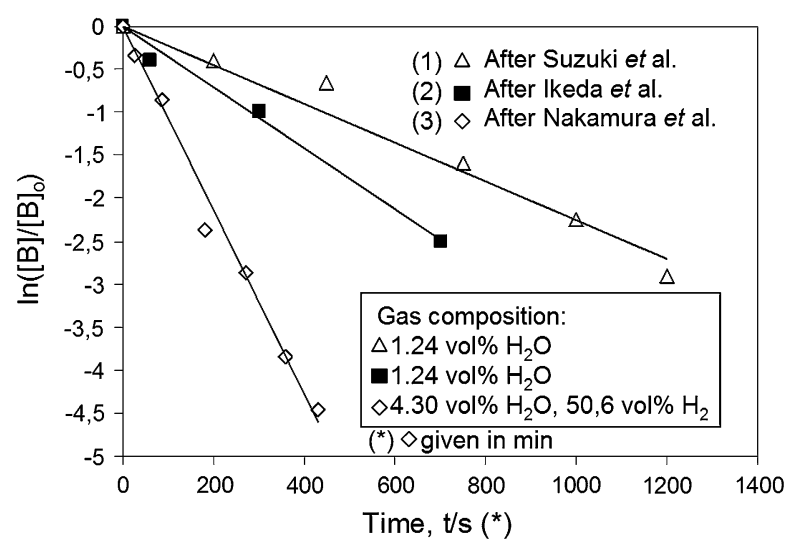

Fig. 2-Logarithmic plot of boron concentration $v s$ time during plasma refining of silicon. ${ }^{[16-18]}$ 


\section{EXPERIMENTAL}

The experimental setup will now be explained in more detail.

\section{A. Gas Purging Experiments}

Three different vapor treatment series (series 1 through 3) have been carried out in this work. The series consist of 14 different experiments and are summarized in Table I. Some of the experiments have been repeated to verify the data obtained (denoted I, II, or III).

All experiments were carried out with $200 \mathrm{~g}$ EG-Si and with targeted boron content of 130 ppmw except for series 1 where the concentration was $150 \mathrm{ppmw}$. In series 1, two different $\mathrm{H}_{2} \mathrm{O}$ contents ( $7.4 \mathrm{vol}$ pct and 3.2 vol pct) were used in combination with pure $\mathrm{H}_{2}$ gas at $1773 \mathrm{~K}\left(1500{ }^{\circ} \mathrm{C}\right)$. In series 2 , the gas composition was kept constant $\left(\mathrm{H}_{2}+3.2\right.$ vol pet $\left.\mathrm{H}_{2} \mathrm{O}\right)$ while varying

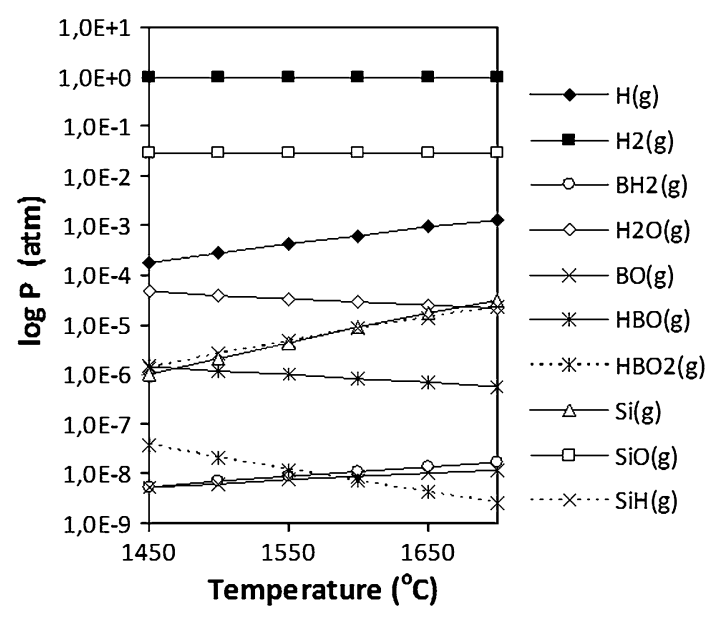

Fig. 3- Graphical representation of FactSage (Thermfact/CRCT, Montreal, Canada) calculations of partial pressure of gaseous species vs temperature in the $\mathrm{H}_{2}-3.2$ vol pet $\mathrm{H}_{2} \mathrm{O}-\mathrm{Si}-\mathrm{B}$ system ( $\mathrm{B} / \mathrm{Si}$ ratio: $\left.10 \times 10^{-6}\right)$. Thermodynamic data are taken from latest NISTJANAF. ${ }^{[23]}$ the temperature of the melt among $1723 \mathrm{~K}, 1823 \mathrm{~K}$, and $1873 \mathrm{~K}\left(1450{ }^{\circ} \mathrm{C}, 1550{ }^{\circ} \mathrm{C}\right.$, and $\left.1600{ }^{\circ} \mathrm{C}\right)$. In the last series (series 3 ), the temperature and the water content were kept constant, respectively, at $1773 \mathrm{~K}\left(1500{ }^{\circ} \mathrm{C}\right)$ and 3.2 vol pct, while changing the $\mathrm{H}_{2}$ - $\mathrm{Ar}$ mixtures. Finally, experiment number 14 was carried out with $\mathrm{H}_{2}$ gas and no water addition at $1773 \mathrm{~K}\left(1500{ }^{\circ} \mathrm{C}\right)$. All the experiments lasted for 4.5 hours or were ended earlier because of technical problems, as shown in Table I. At the end, the molten silicon was cast into a copper mold.

\section{B. Furnace and Gas Purging Setup}

Figure 4 shows a schematic drawing of the $45-\mathrm{kW}$ induction furnace used in this work. The furnace

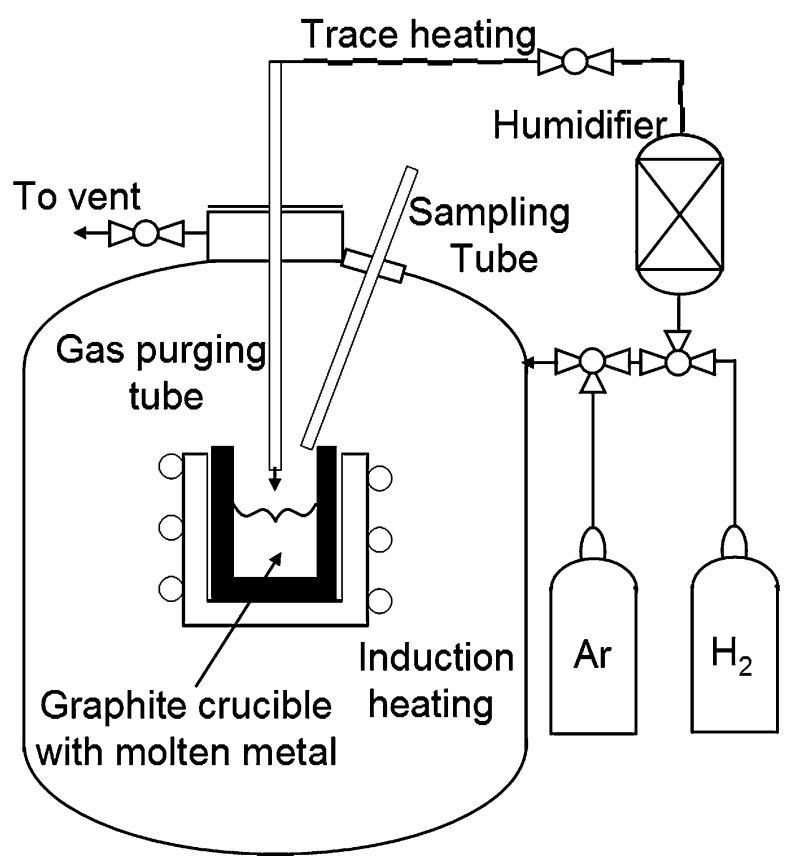

Fig. 4-Schematic drawing of a vacuum-induction furnace equipped with gas purging unit.

Table I. List of Experiments (1 through 14)

\begin{tabular}{|c|c|c|c|c|c|c|}
\hline & Exp. No. & Temperature $\left[\mathrm{K}\left({ }^{\circ} \mathrm{C}\right)\right]$ & $\mathrm{Vol}$ pet $\mathrm{H}_{2} \mathrm{O}$ & Vol pct Purge Gas & Duration (h) & Boron Addition \\
\hline \multirow[t]{2}{*}{ Series 1} & 1 & $1773(1500)$ & 7.4 & 92.6 pct $\mathrm{H}_{2}$ & 2 & $150 \mathrm{ppmw}$ \\
\hline & 2 & $1773(1500)$ & 3.2 & 96.8 pct $\mathrm{H}_{2}$ & 4.5 & $150 \mathrm{ppmw}$ \\
\hline \multirow[t]{6}{*}{ Series 2} & 3 & $1723(1450) \mathrm{I}$ & 3.2 & 96.8 pct $\mathrm{H}_{2}$ & 4.5 & $130 \mathrm{ppmw}$ \\
\hline & 4 & $1723(1450) \mathrm{II}$ & 3.2 & 96.8 pct $\mathrm{H}_{2}$ & 1.5 & $130 \mathrm{ppmw}$ \\
\hline & 5 & 1723 (1450)III & 3.2 & 96.8 pct $\mathrm{H}_{2}$ & 4.5 & $130 \mathrm{ppmw}$ \\
\hline & 6 & $1823(1550) \mathrm{I}$ & 3.2 & 96.8 pet $\mathrm{H}_{2}$ & 4.5 & $130 \mathrm{ppmw}$ \\
\hline & 7 & $1823(1550) \mathrm{II}$ & 3.2 & 96.8 pct $\mathrm{H}_{2}$ & 4.5 & $130 \mathrm{ppmw}$ \\
\hline & 8 & $1873(1600)$ & 3.2 & 96.8 pct $\mathrm{H}_{2}$ & 4.5 & $130 \mathrm{ppmw}$ \\
\hline \multirow[t]{6}{*}{ Series 3} & 9 & $1773(1500)$ & 3.2 & 96.8 pet $\mathrm{Ar}$ & 4.5 & $130 \mathrm{ppmw}$ \\
\hline & 10 & $1773(1500) \mathrm{I}$ & 3.2 & 24.2 pct $\mathrm{H}_{2}-72.6$ pet $\mathrm{Ar}$ & 4.5 & $\sim 50 \mathrm{ppmw}$ \\
\hline & 11 & $1773(1500) \mathrm{II}$ & 3.2 & 24.2 pct $\mathrm{H}_{2}-72.6$ pct $\mathrm{Ar}$ & 4.5 & $130 \mathrm{ppmw}$ \\
\hline & 12 & $1773(1500)$ & 3.2 & 48.4 pct $\mathrm{H}_{2}-48.4$ pet $\mathrm{Ar}$ & 4.5 & $130 \mathrm{ppmw}$ \\
\hline & 13 & $1773(1500)$ & 3.2 & 72.6 pct $\mathrm{H}_{2}-24.2$ pet $\mathrm{Ar}$ & 4.5 & $130 \mathrm{ppmw}$ \\
\hline & 14 & $1773(1500)$ & 0 & $\mathrm{H}_{2}$ & 4.5 & $130 \mathrm{ppmw}$ \\
\hline
\end{tabular}


consists of a vacuum chamber and an inductive-heated graphite crucible $(6.4 \mathrm{~cm}$ inner diameter $)$, which contains the liquid silicon with a top surface area $(A)$ of $32.2 \mathrm{~cm}^{2}$. Water vapor was added to the hydrogenargon mixture in the humidifier and then the gas was sparged on top of the silicon using heated quartz tubes. The humidifier consists of a temperature-controlled water bath and a dispersion stone. A gas flow of $3 \mathrm{~L} / \mathrm{min}$ was applied in all the experiments. Quartz tubes were used to sample the melt every 30 minutes.

Fluent $6.3,{ }^{[26]}$ a commercially available software, was used to simulate the silicon melt and gas velocity at $1773 \mathrm{~K}\left(1500{ }^{\circ} \mathrm{C}\right)$ during sparging with $\mathrm{H}_{2}$ gas for the experimental setup in this work (Figures 5(a) and (b)) (the simulation is two-dimensional, transient, and nonaxisymmetric). The purpose of this was to investigate the interface area between the gas phase and the silicon melt. After 4 seconds, the melt is at a steady state and the impingement of the gas causes small ripples on the surface. Disregarding the ripples, the melt is relatively flat. It is, therefore, a good approximation to use the inner surface area $(A)$ of the crucible as the reaction area in the mass transfer calculations shown later in this work.

\section{Analysis Methods}

Simple resistivity measurements were used to investigate the boron content in all the samples retrieved from the refining experiments. The samples were first cast in epoxy, polished (1000 mesh), and then the resistivity was measured with a Jandel 4 point probe (Jandel Engineering, Ltd., Bedfordshire, U.K.) as shown in Figure 6.

The boron content was then calculated using the following empirical equation from eight resistivity measurements per sample ${ }^{[28]}$ :

$$
N=\frac{A}{\rho}+\frac{B}{\rho\left[1+(C \rho)^{1.105}\right]}
$$

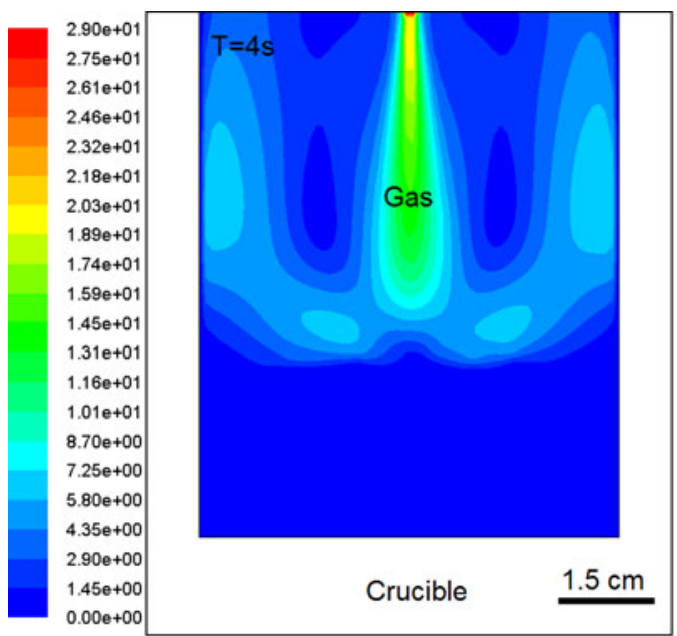

(a) where $N$ is the dopant density $\left(\mathrm{cm}^{-3}\right), \rho$ is the resistivity $(\Omega \cdot \mathrm{cm}), A$ is $1.33 \times 10^{16}\left(\Omega \cdot \mathrm{cm}^{-2}\right), B$ is $1.082 \times 10^{17}$ $\left(\Omega \cdot \mathrm{cm}^{-2}\right)$, and $C$ is $54.56\left(\Omega^{-1} \cdot \mathrm{cm}^{-1}\right)$.

To verify the resistivity measurements, parallel ICPmass spectrometry (MS) analyses were carried out on specimens No. 1 and 2 in series 1 (Table I). The samples were prepared and analyzed at the Norwegian University of Science and Technology.

\section{RESULTS}

\section{A. Silicon Yield}

The Si yield was found by weighing the silicon before and after each experiment. The mass of silicon $\left(\mathrm{m}_{\mathrm{Si}}\right)$ lost, sampled, and cast for all the 14 experiments are displayed in Figure 7.

The average loss of mass for the 4.5-hour experiments is 10.73 pct \pm 2.85 pct. The deviations in weight loss between the different experiments seem random. However, some silicon may not have been accounted for

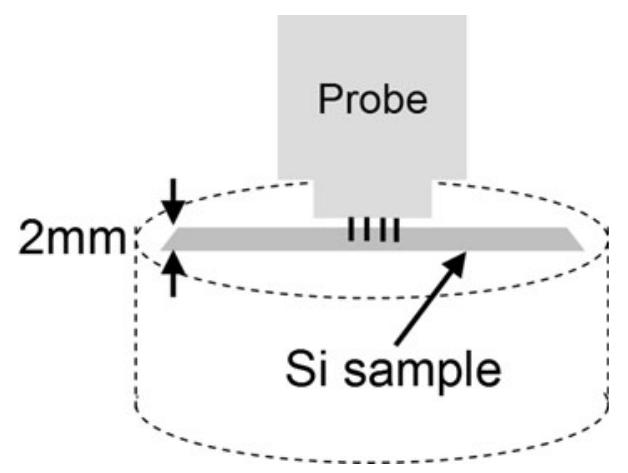

Fig. 6-Schematic illustration of the Jandel four-point probe used in this work to measure resistivity of samples retrieved from the gas purging experiments.

Fig. 5-Simulations of the gas velocity $(a)$ and Si-melt velocity $(b)$ in $\mathrm{m} / \mathrm{s}$ after $4 \mathrm{~s}$ for the experimental setup in this work (Fluent 6.3 ). Thermophysical data have been taken from Rhim et al. ${ }^{[27]}$ 


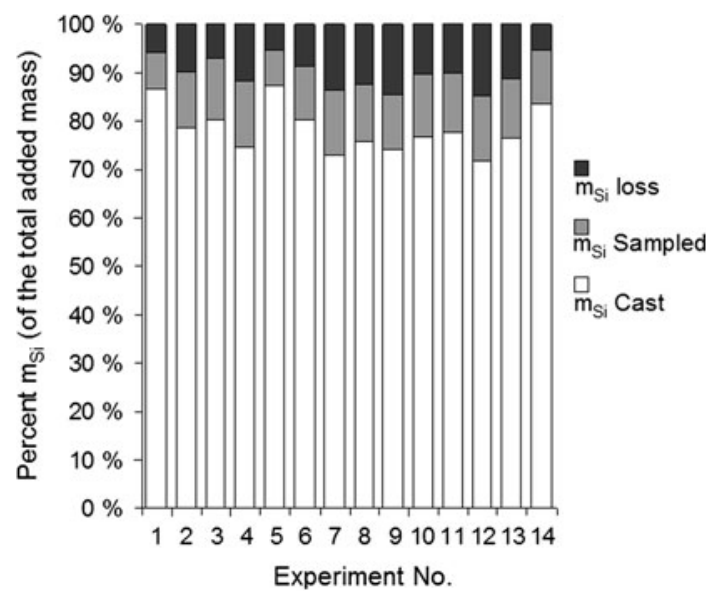

Fig. 7-Graphical representation of the mass of silicon lost, sampled, and cast for all 14 experiments.

because of splashing during casting and sampling. Furthermore, the silicon loss from oxidation refining seems small when compared with the weight loss reported for experiment No. 14 where no water (oxygen) was added. The total amount of silicon sampled was close to $25 \mathrm{~g}$ in each experiment.

\section{B. Boron Analysis}

The main results from ICP-MS analysis and resistivity measurements are presented in the next three sections as series I, II, and III. The series refer to the experiments listed in Table I.

\section{Series $I$}

In Figure 8(a), the ICP-MS results and resistivity measurements of two experiments in series I (Table I) are plotted $v s$ time. The data points from the ICP-MS measurements correlate with the resistivity analysis. However, the boron content analyzed by ICP-MS is on average approximately 35 pct higher than the values obtained from resistivity analysis. In both experiments, the boron content drops dramatically when the melts are being treated with moist hydrogen. Furthermore, the high water content experiment shows significant lower boron content after 2 hours treatment. The experiment was terminated at this time because of the extensive growth of crystalline quarts from the crucible wall. The effect of water was not pursued more in this work.

\section{Series $I I$}

The results from the resistivity measurements of the refining experiments in series II are plotted in Figure 8(b). In this series, three different silicon melt temperatures have been investigated (Table I). In all the experiments, the refining is highly effective and the boron content is reduced to well below 1 ppmw after 4.5 hours of treatment. Figure 8(b) also displays with a dotted line the refining experiments that were repeated several times. The data points correlate well with the first experiments that indicate good reproducibility. The boron yield, as shown by the first data point on the graphs, is usually 40 ppmw lower than the targeted boron content of $130 \mathrm{ppmw}$. The discrepancy is probably caused by some preoxidation of the added boron powder during heating.

\section{Series III}

In Figure 8(c), the results from the resistivity measurements of the six experiments in series III (Table I) have been plotted $v s$ time. In this series, the effect of hydrogen content in the purge gas mixture has been investigated. Figure 8(c) immediately reveals that $\mathrm{H}_{2}$ addition increases the removal rate of boron significantly. It also shows that boron removal using pure $\mathrm{H}_{2}$ (no water) is slow, proving that boron refining in practice cannot be done with $\mathrm{H}_{2}$ gas alone. In experiment No. 10 (24.2 pct $\mathrm{H}_{2}-72.6$ pct Ar), the boron yield was expected to be low because of some accidental preheating in air. An additional experiment was therefore carried out, as shown in Figure 8(c), by a dotted line.

\section{Boron Mass Transfer}

Figures 9(a) and (b) show logarithmic plots of the boron content $\left([\mathrm{B}] /[\mathrm{B}]_{\mathrm{o}}\right)$ as a function of refining time $((A / V) \cdot t)$ for the experiments carried out at different temperatures (Nos. 3 through 8) and different $\mathrm{H}_{2}$ contents (Nos. 2 and 9 through13), respectively. The amount of silicon lost and sampled previously presented in Section IV-A have been taken into account. Furthermore, the values for the mass transfer coefficients $\left(k^{\prime}, \mathrm{m} /\right.$ s) in Figure 9 have been obtained from the slopes of each plot. The linearity of the plots shows that boron evaporation follows first-order rate kinetics, which is in agreement with published literature for plasma refining (previously presented in Section II-B).

\section{Effect of Silicon Oxidation}

In prior plasma gas experiments, it has been reported that $\mathrm{SiO}_{2}$ formation on the surface will have a large impact on the removal rate of boron. This was not found in this work. In all the experiments, some crystalline quartz formed on the crucible wall. Only in the 7.4 vol pct $\mathrm{H}_{2} \mathrm{O}$ experiment (experiment 1), the quartz started to grow horizontally to cover the surface. That growth may have affected the removal rate to some extent because of the reduced reaction area. Furthermore, there was no visual increase in $\mathrm{SiO}_{2}$ formation when the $\mathrm{H}_{2}$ content was reduced. The theory presented in Section II-A about $\mathrm{H}_{2}$ gas increasing the boron evaporation by suppressing $\mathrm{SiO}_{2}$ formation seems unlikely according to the findings in this work.

\section{DISCUSSION}

\section{A. Resistivity Measurements}

Resistivity measurements are a cheap and easy method to investigate the boron content in silicon. In addition, it will produce results in a relatively short time. 


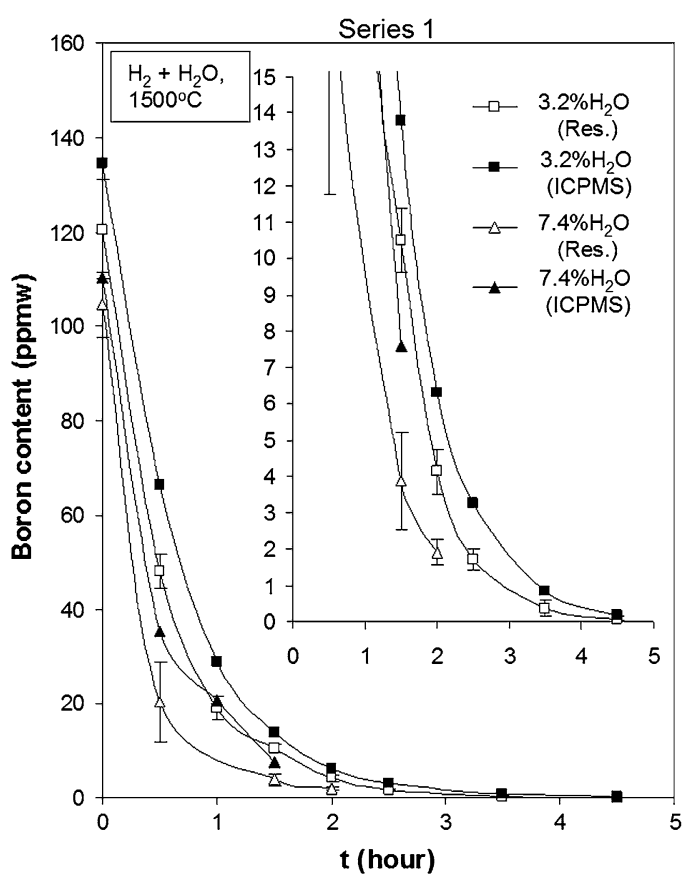

(a)

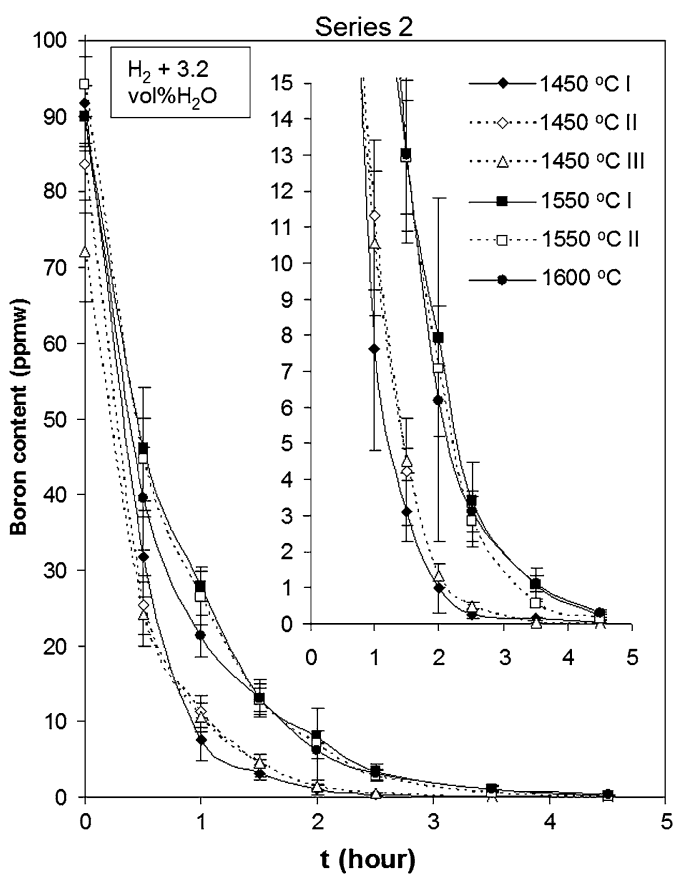

(b)

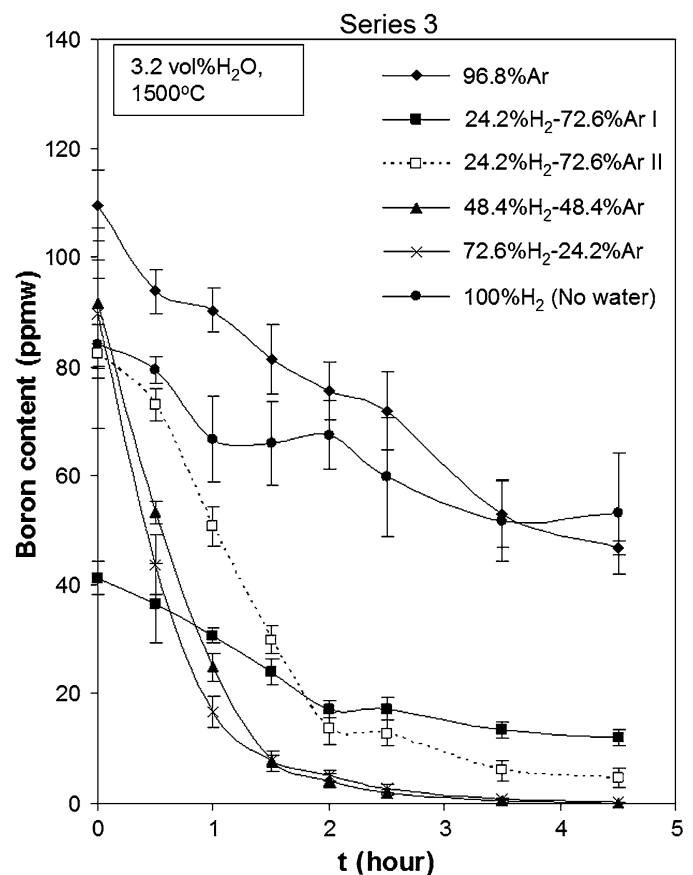

(c)

Fig. 8-Plotted results from the ICP-MS and the resistivity measurements of the 14 experiments in series I, II, and III (Table I), showing the boron content in the melt vs time. (a) Experiments carried out with different water contents. (b) Experiments carried out at different temperatures. $(c)$ Experiments carried out with different $\mathrm{H}_{2}$ contents. The error bars in the graphs indicate the standard deviation in resistivity measurements.

Its application is, first of all, intended for high-purity boron doped silicon, as used in this work. However, the probe used for measuring the resistivity should not be closer to the edge of the sample than four times the probe size $(4 \times 0.635 \mathrm{~mm}$. Therefore, the discrepancy between the ICP-MS and the resistivity measurements in this work is possibly an "edge" effect caused by the small sample radius $(\sim 1 \mathrm{~mm})$. It is believed that this effect is nearly constant for all the resistivity measurements, meaning that the results are comparable with each other. Another source of error is grain boundaries that can contribute to higher resistivity if measured across. However, it has been reported by others that the correlation between the boron content found by 


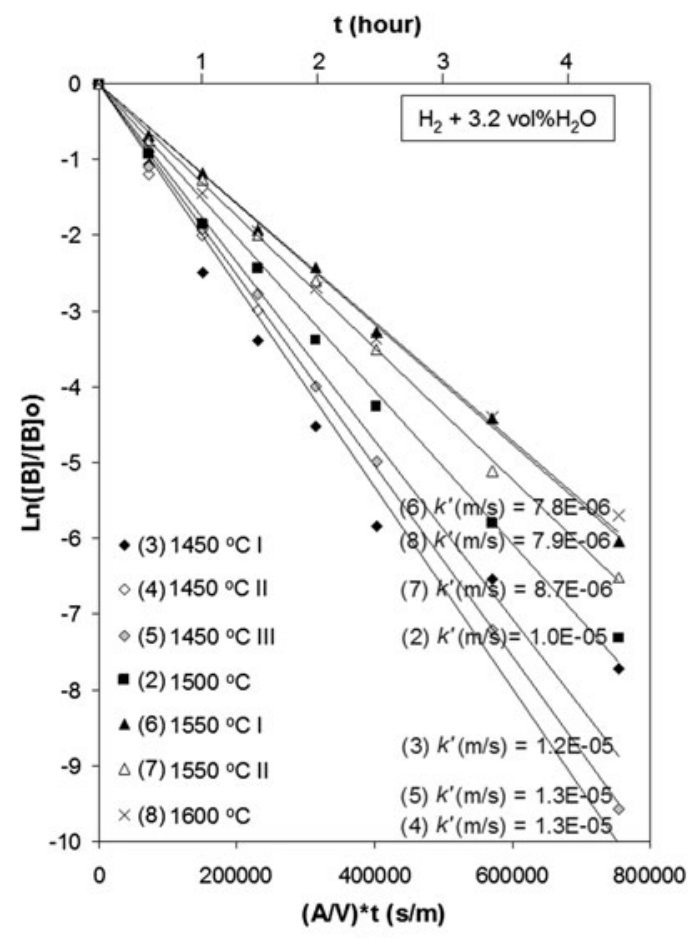

(a)

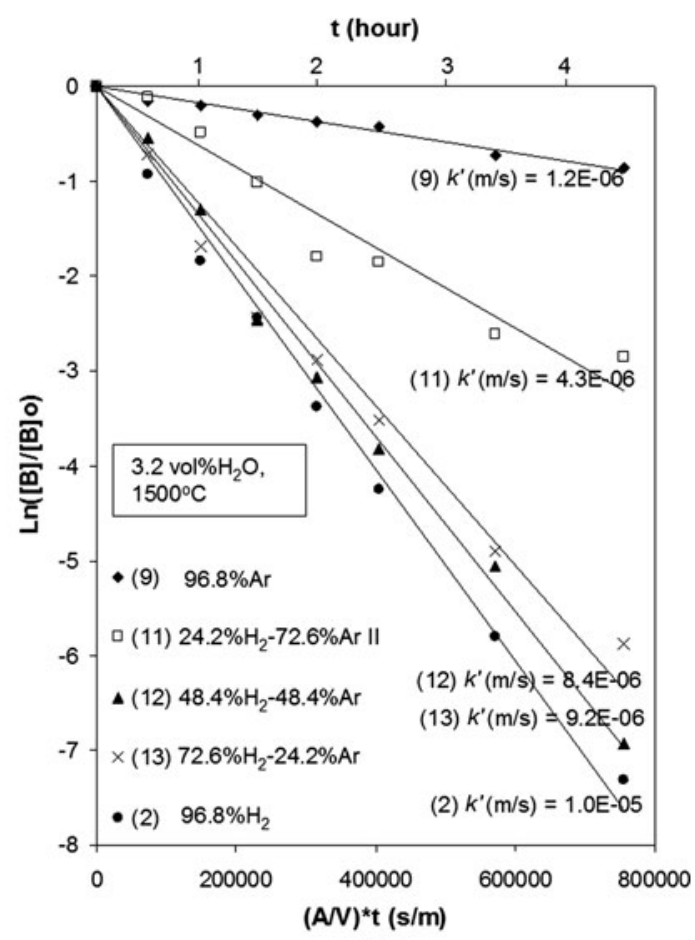

(b)

Fig. 9-Logarithmic plot of the boron content $\left([\mathrm{B}] /[\mathrm{B}]_{\mathrm{o}}\right)$ vs refining time $((A / V) \cdot t)$ of experiments carried out at different temperatures $(a)$ and different $\mathrm{H}_{2}$ contents $(b)$. The numbers (2 through 13 ) refer to experiments listed in Table I.

chemical analysis and resistivity in boron doped multicrystalline EG-Si is good. ${ }^{[29]}$

\section{B. Kinetics of Boron Gaseous Removal}

The kinetics of boron transfer from the silicon melt to a surrounding gas can be divided into five steps ${ }^{[30]}$ :

(a) Transport in the silicon melt

(b) Diffusion through a stagnant boundary layer close to the interface (liquid side)

(c) Chemical reaction among $\mathrm{B}, \mathrm{H}_{2} \mathrm{O}$, and $\mathrm{H}_{2}$ at the interface

(d) Diffusion through a stagnant boundary layer close to the interface (gas side)

(e) Transport in the gas phase

Transport in the melt and gas phase can always be considered fast in small-scale experiments where shallow melts are inductionally stirred and gas sparging is used. Steps (a) and (e) are not likely to be the rate-limiting steps. Close to the interface, the movements of gas and melt are slow and horizontal, and the transport of boron is dependent of the slow mechanism of diffusion. Furthermore, diffusion is strongly dependent on temperature and increases roughly exponentially as temperature increases (Arrhenius). However, the temperature dependents of the boron mass transfer, summarized in Figure 10, clearly demonstrate that the deboronization rate of silicon in the current study decreases with increasing temperature.

This also corresponds with the thermodynamic calculations presented in Figure 3, which predict a decrease

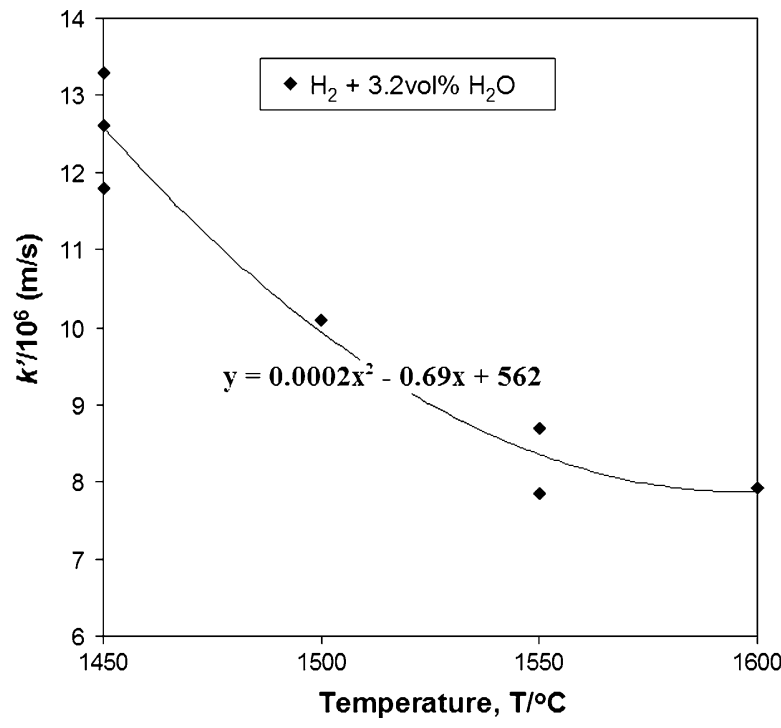

Fig. 10-Relationship between the mass transfer coefficient $\left(k^{\prime}\right)$ of boron and temperature in silicon treated with $\mathrm{H}_{2}+3.2$ vol pct $\mathrm{H}_{2} \mathrm{O}$. Trendline is expressed as a second-order polynomial.

in the partial pressure of the boron oxyhydrides with increasing temperature. It is, therefore, most likely that the rate is controlled by the chemical reaction among $\mathrm{B}$, $\mathrm{H}_{2} \mathrm{O}$, and $\mathrm{H}_{2}$ at the liquid/gas interface (step 3). There are several findings to support this: First, the removal rate is affected by the $\mathrm{H}_{2} \mathrm{O}$ content in the gas as previously shown in Section IV-B-1. When the water vapor content is close to doubled from experiment No. 1 


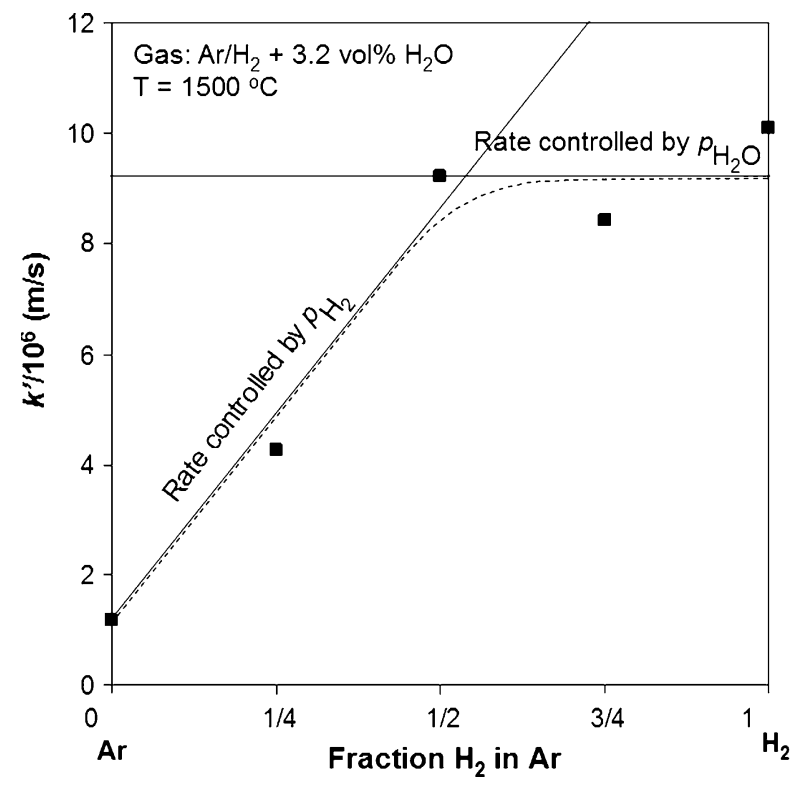

Fig. 11-Relationship between fraction $\mathrm{H}_{2}$ in Ar and boron mass transfer in silicon treated at $1773 \mathrm{~K}\left(1500{ }^{\circ} \mathrm{C}\right)$ with 3.2 vol pet $\mathrm{H}_{2} \mathrm{O}$.

to experiment No. 2, the reaction rate $\left(k^{\prime}\right)$ increases from $1.0 \times 10^{5}$ to $1.4 \times 10^{5}$ (calculations based on resistivity data in Figure 8(a)). This increase corresponds with a half-order relation of water on the removal rate $\left(p \mathrm{H}_{2} \mathrm{O}^{1 / 2}\right)$, which had been reported by Theuerer. ${ }^{[15]}$ Second, the removal rate drops rapidly when the $\mathrm{H}_{2}$ content in the gas mixture is reduced. This is shown in Figure 11 where the results from the boron mass transfer calculations are plotted against fraction $\mathrm{H}_{2}$ in the gas mixture.

In Figure 11, it is schematically illustrates that the rate is dominated by $p_{\mathrm{H}_{2} \mathrm{O}}$ above 50 pct $\mathrm{H}_{2}$ added, meaning that $\mathrm{H}_{2}$ at this point is in excess. As the $\mathrm{H}_{2}$ content is reduced at constant $p_{\mathrm{H}_{2} \mathrm{O}}$, the rate is eventually controlled by the $p_{\mathrm{H}_{2}}$. The slope further suggests that the effect of $\mathrm{H}_{2}$ on the removal rate is first order up to $50 \mathrm{pct}$ and zero order above. However, more experimental data are needed to in the future to confirm this relation.

From Figure 11, it is possible that the $\mathrm{H}_{2}$ content should be at least 50 pct to obtain the highest boron removal rate at $1773 \mathrm{~K}\left(1500{ }^{\circ} \mathrm{C}\right)$ when 3.2 vol pet $\mathrm{H}_{2} \mathrm{O}$ is used. It is difficult to explain why such a high amount of $\mathrm{H}_{2}$ is needed in the gas mixture compared with the water content. One possibility is that the dissociation of $\mathrm{H}_{2}$ into free hydrogen $(\mathrm{H})$, which can react to form $\mathrm{HBO}$, is small. This can explain why plasma treatment is six times faster than gas blowing $\left(k^{\prime}: 7.7 \times 10^{-5} v s\right.$ $1.3 \times 10^{-5}$, respectively). Because plasma consists of ionized gases the amount of $\mathrm{O}$ and $\mathrm{H}$ free to react with boron is much higher.

\section{CONCLUSIONS}

The basic conclusions that can be drawn from this work are as follows:

1. Boron is removed from liquid silicon by blowing moist hydrogen on top of the melt.
2. Water vapor treatment of molten silicon can alone remove boron. However, in combination with hydrogen gas, the removal rate is significantly increased.

3. It is found that approximately $50 \mathrm{vol} \mathrm{pct} \mathrm{H}_{2}$ in the treatment gas is sufficient to maintain a high boron removal rate at $1773 \mathrm{~K}\left(1500{ }^{\circ} \mathrm{C}\right)$ when $3.2 \mathrm{vol}$ pct $\mathrm{H}_{2} \mathrm{O}$ is used.

4. Gas treatment with pure $\mathrm{H}_{2}$ has little effect on boron removal, which indicates that boron is mainly evaporated as oxyhydride species.

5. The rate of boron removal in current gas purging experiments is controlled by chemical reaction depending on $p_{\mathrm{H}_{2} \mathrm{O}}$ and $p_{\mathrm{H}_{2}}$.

6. The rate of boron removal from silicon decreases with increasing temperature between $1723 \mathrm{~K}$ and $1873 \mathrm{~K}\left(1450{ }^{\circ} \mathrm{C}\right.$ and $\left.1600{ }^{\circ} \mathrm{C}\right)$.

\section{ACKNOWLEDGMENTS}

I would like to acknowledge Dr. Jeffrey Cline (NTNU) for all the fruitful discussions we have had and for his big contribution to the experimental part. I would also like to thank Dr. Kai Tang (SINTEF) and Dr. Mehdi Kadkhodabeigi (ERAMET) for helping me with the thermodynamic calculations and the CFD modeling, respectively.

\section{OPEN ACCESS}

This article is distributed under the terms of the Creative Commons Attribution License which permits any use, distribution, and reproduction in any medium, provided the original author(s) and the source are credited.

\section{REFERENCES}

1. H.A. Aulich and F.W. Schulze: Progr. Photovoltaics, 2002, vol. 10 (2), pp. 141-47.

2. D. Lynch: $J O M, 2009$, vol. 61 (11), pp. 41-48.

3. B.R. Bathey and M.C. Cretella: J. Mater. Sci., 1982, vol. 17 (11), pp. 3077-96.

4. A. Schei: EP699625A1, 1996.

5. N. Nakamura, M. Abe, K. Hanazawa, H. Baba, N. Yuge, Y. Sakaguchi, Y. Kato, F. Aratani, and K. Saito: EP855367A1, 1998.

6. B. Monsen, O. Raaness, R. Jensen, K. Kleveland, S. Prytz, B. Ravary, J.A. Bakken, and A. Westermoen: WO2006135253A1, 2006.

7. K. Morita and T. Miki: Intermetallics, 2003, vol. 11 (11, 12), pp. 1111-17.

8. E.H. Myrhaug and H. Tveit: Electr. Furn. Conf. Proc., Iron Steel Society, 2000, vol. 58, pp. 591-604.

9. J. Amouroux, D. Morvan, and A. Gicquel: Fresenius Zeitschrift Fur Analytische Chemie, 1986, vol. 324 (5), pp. 384-96.

10. N. Yuge, H. Baba, Y. Sakaguchi, K. Nishikawa, H. Terashima, and F. Aratani: Sol. Energ. Mater. Sol. Cell., 1994, vol. 34 (1-4), pp. $243-50$.

11. T. Ikeda and M. Maeda: ISIJ Int., 1992, vol. 32 (5), pp. 635-42.

12. J.J. Wu, W.H. Ma, B. Yang, Y.N. Dai, and K. Morita: Trans. Nonferr. Met. Soc. China, 2009, vol. 19 (2), pp. 463-67.

13. K. Suzuki, T. Sugiyama, K. Takano, and N. Sano: ISIJ Int., 1990, vol. 54 (2), pp. 168-72. 
14. H. Fujiwara, J.Y. Liang, K. Miyata, E. Ichise, and R. Otsuka: Nippon Kinzoku Gakkaishi, 1996, vol. 60, pp. 65-71.

15. H.C. Theuerer: Trans. Am. Inst. Min. Metall. Eng., 1956, vol. 206 (10), pp. 1316-19.

16. K. Suzuki, T. Kumagai, and N. Sano: ISIJ Int., 1992, vol. 32 (5), pp. 630-34.

17. T. Ikeda and M. Maeda: Mater. Trans. JIM, 1996, vol. 37 (5), pp. $983-87$.

18. N. Nakamura, H. Baba, Y. Sakaguchi, and Y. Kato: Mater. Trans., 2004, vol. 45 (3), pp. 858-64.

19. C. Alemany, C. Trassy, B. Pateyron, K.I. Li, and Y. Delannoy: Sol. Energ. Mater. Sol. Cell., 2002, vol. 72 (1-4), pp. 41-48.

20. A. Yvon, E. Fourmond, C. Ndzogha, Y. Delannoy, and C. Trassy: 4th Int. Conf. on Electromagnetic Processing of Materials, Lyon, France, 2003, pp. 342-43.

21. J.V.D. Avyle, P. Ho, and J.M. Gee: Sand200-0821, Sandia National Laboratories, Livermore, CA, 2000.

22. Thermfact/CRCT and GTT Technologies, http://www.factsage. com.
23. M.W. Chase, Jr.: NIST JANAF Thermochemical Tables, American Chemical Society and the American Institute of Physics for the National Institute of Standards and Technology, Woodbury, NY, 1998.

24. B.P. Lee, H.M. Lee, D.H. Park, J.S. Shin, T.U. Yu, and B.M. Moon: Sol. Energ. Mater. Sol. Cell., 2011, vol. 95 (1), pp. 56-58.

25. C.P. Khattak, F. Schmid, D.B. Joyce, E.A. Smelik, and M.A. Wilkinson: AIP Conf. Proc., 1999, vol. 462, pp. 731-36.

26. ANSYS. Inc., http://www.ansys.com.

27. W.K. Rhim, S.K. Chung, A.J. Rulison, and R.E. Spjut: Int. J. Thermophys., 1997, vol. 18 (2), pp. 459-69.

28. ASTM F 723-97, "Standard Practice for Conversion Between Resistivity and Dopant Density for Boron-Doped and PhosphorusDoped, and Arsenic-Doped Silicon," 1997.

29. M. Di Sabatino, E.J Øvrelid, and E. Olsen: 21st European Photovoltaic Solar Energy Conf., Dresden, Germany, 2006, pp. 106871.

30. T.A. Engh: Principles of Metal Refining, Oxford University Press, Oxford, U.K., 1992, pp. 171-218. 